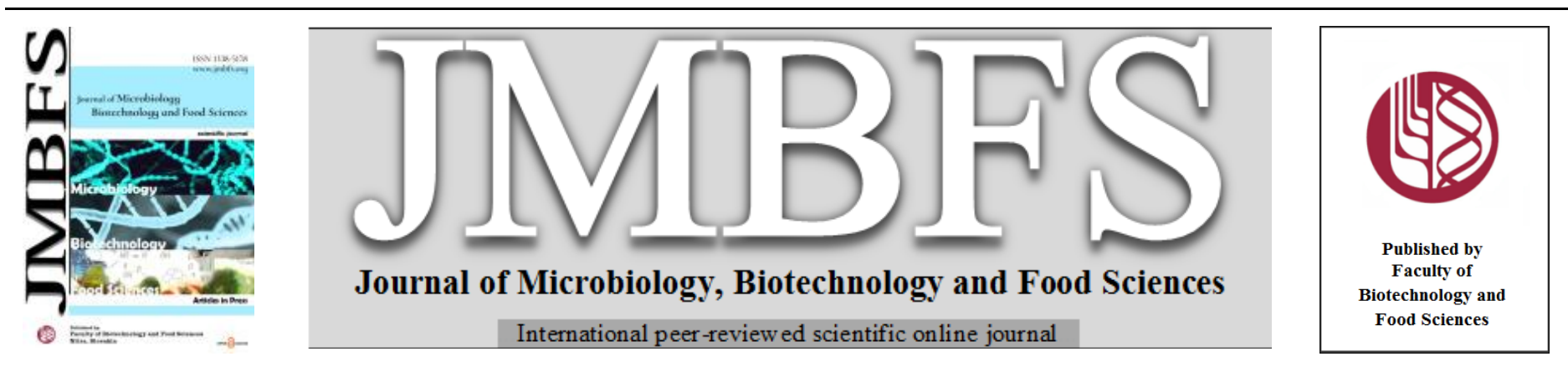

\title{
IN VITRO ASSESSMENT OF THE ANTIVIRAL ACTIVITY OF GREEK BEE BREAD AND BEE COLLECTED POLLEN AGAINST ENTEROVIRUS D68
}

\author{
Nikos Asoutis Didaras ${ }^{1 \dagger}$, Tilemachos G. Dimitriou ${ }^{1 \dagger}$, Maria Daskou ${ }^{1}$, Katerina Karatasou ${ }^{2}$ and Dimitris Mossialos $^{* 1}$
}

Address(es): Dr Dimitris Mossialos,

${ }^{1}$ University of Thessaly, Laboratory of Microbial Biotechnology - Molecular Bacteriology - Virology, Department of Biochemistry \& Biotechnology, Biopolis, 41500, Larissa, Greece.

${ }^{2}$ Apicultural Centre of Larissa, Federation of Greek Beekeepers Associations, Kouma 4, 41222, Larissa, Greece.

${ }^{\dagger}$ Authors contributed equally to this work.

*Corresponding author: mosial@bio.uth.gr

https://doi.org/10.55251/jmbfs.4859

\section{ARTICLE INFO}

Received 4. 6. 2021

Revised 29. 10. 2021

Accepted 1. 10. 2021

Published 1. 2. 2022

Regular article

OPEN $\partial$ ACCESS

\begin{abstract}
Bee bread is derived from bee collected pollen which is processed by the bee, fermented and stored in the hive. Few studies have assessed the antimicrobial activity of bee bread against major bacterial pathogens and fungi. However, to the best of our knowledge, neither bee collected pollen nor bee bread, have so far been investigated for their antiviral properties. In the present study, 18 Greek bee bread and 2 pollen samples from different botanical sources and geographical locations were assessed regarding their in vitro antiviral activity against Enterovirus D68. A cell culture assay combined with a comparative Real-Time PCR assay was performed using different sample concentrations to assess the antiviral activity. MTT assay was implemented in order to calculate the sample toxicity levels on cell culture. Our data suggest that Greek bee bread and bee collected pollen exhibit potent antiviral activity against EV-D68 with $\mathrm{IC}_{50}$ values ranging from 0.048 to $5.45 \mathrm{mg} / \mathrm{ml}$. Greek bee bread and bee collected pollen are promising sources of antiviral compounds and should be further studied against diverse viruses in order to explore their full antiviral potential.
\end{abstract}

Keywords: Antiviral, Enterovirus, Bee Bread, Pollen, Bee Hive Products

\section{INTRODUCTION}

Bee bread (BB) is a honey bee product derived from bee collected pollen (BCP), processed, fermented and stored in the hive. Fermentation of BCP is catalyzed by bee enzymes and microorganisms (bacteria, molds and yeasts), leading to a more nutritious product. BB consists of proteins, carbohydrates, lipids and fatty acids, vitamins, micro- and macro elements and phenolic compounds (Didaras et al., 2020). Few studies have demonstrated the antimicrobial activity of BB against major bacterial pathogens and fungi (Didaras et al., 2020; Pełka et al., 2021). However, the antiviral activity of BB and BCP has not been studied. Lee et al. have studied the antiviral activity against Influenza A strains of certain BCP compounds of Korean Papaver rhoeas (Lee et al., 2016). Other bee products, namely honey, royal jelly, propolis and bee venom were investigated regarding their antiviral properties. Furthermore, bee products have been recently tested for their possible use against SARS-CoV -2 (Abu-Serie \& Habashy, 2019; Berretta et al., 2020; Hood et al., 2013; Hossain et al., 2020; Lima et al., 2021; Uddin et al., 2016). Enterovirus D68 (EV-D68) belongs to genus Enterovirus of the Picornaviridae family having characteristics of both the Enterovirus (EV) and Rhinovirus (RV) species. The genome consists of a 7.500nt single stranded positive sense RNA (+ssRNA). EV-D68 was first isolated and identified in 1962 (Oberste et al., 2004). Since then, reports of EV68 isolation have been very uncommon, until 2014 when severe respiratory illness associated with a nationwide outbreak of EV-D68 was reported in the USA (Midgley $\boldsymbol{e t}$ al., 2015). Most of the infected patients were children and the clinical manifestations varied from mild to severe respiratory symptoms. Furthermore, recent studies have implicated EV-D68 with acute flaccid myelitis (AFM) (Aliabadi et al., 2016; Hu et al., 2019; Mishra et al., 2019).

Against EV-D68 there are no licensed therapies to prevent infection or AFM disease (Vogt et al., 2020). Drugs targeting picornaviruses and enteroviruses have been developed but none of them has shown activity against EV-D68 at clinically relevant concentrations (Oermann et al., 2015).

In this study, $18 \mathrm{BB}$ and $2 \mathrm{BCP}$ samples from different botanical sources were assessed in vitro regarding their antiviral activity against EV-D68.

\section{MATERIALS AND METHODS}

Bee bread (BB), bee collected pollen (BCP) samples and virus strain

A total of $18 \mathrm{BB}$ and $2 \mathrm{BCP}$ samples harvested in different regions of Greece between March-October 2019 were provided by beekeepers. Each sample was assigned a unique reference number, and details regarding the botanical source and geographical location were recorded (Table 2). BB samples were directly collected from honeycombs and then stored in sterile plastic containers at $-20^{\circ} \mathrm{C}$.

Each one of BB and BCP samples was dissolved in Dulbecco's Modified Eagle cell culture medium (D-MEM, LM-D1113, Biosera, France) for one hour (1 h) at room temperature, centrifuged for $10 \mathrm{~min}$ at 10,000 $\mathrm{rcf}$ and then the liquid fraction was filtered through a Branchia $0.22 \mu \mathrm{m}$ syringe filter (Labbox Labware, S.L., Barcelona, Spain). The filtered BB and BCP suspension was serially diluted and used for the assays.

Enterovirus D-68, Fermon (California/62) strain (RIVM, The Netherlands), inoculated in Rhabdomyosarcoma (Rd) cells (human rhabdomyosarcoma cell line-CCL-136 $6^{\mathrm{TM}}$, ATTC) was firstly titred calculating the TCID 50 (Hierholzer \& Killington, 1996), and then serially diluted in order to obtain $10^{2} \mathrm{TCID}_{50} / 0.1 \mathrm{ml}$ virus titre.

\section{Palynological Analysis}

Palynological analysis of the $18 \mathrm{BB}$ and $2 \mathrm{BCP}$ samples in order to characterize the botanical origin was conducted by CheMa laboratories (Korinthos, Greece) as described before (Didaras et al., 2021). In brief, 5-10 mg of each sample was diluted in $1 \mathrm{~mL}$ of deionized water using a vortex mixer and $0.5 \mathrm{~mL}$ of each suspension was spread on a $22 \times 22 \mathrm{~mm}$ area of a microscopy slide and dried at 39 ${ }^{\circ} \mathrm{C}$. The pollen grains were identified using a Euromex BioBlue optical microscope at $400 \times$ magnification. The following databases were used in order to identify the pollen grains: Pollen Atlas, available at pollenatlas.net, the pollen Wiki database and the pollen library at the CheMa laboratories. 


\section{3-(4,5-dimethylthiazol-2-yl)-2,5-diphenyltetrazolium bromide (MTT) assay}

In order to assess the cytotoxicity of BB and BCP samples against Rd cells the MTT colorimetric assay used (van Meerloo et al, 2011). Rd cells in D-MEM supplemented with $2 \%$ fetal bovine serum (FB-1001, Biosera) were seeded in 96 well plates (Biologix Europe, Germany). Cells were incubated for 24 hours at $37^{\circ} \mathrm{C}$ thus forming a monolayer. After that, the medium was removed and $100 \mu \mathrm{l}$ of each $\mathrm{BB}$ or BCP dilution in D-MEM medium containing were added on the 96 well plate in triplicates. The final concentrations of tested $\mathrm{BB}$ and $\mathrm{BCP}$ samples ranged from 16 to $0.0625 \mathrm{mg} / \mathrm{ml}$ (two-fold dilutions). A cell control containing only $\mathrm{Rd}$ cells was used in triplicate as a negative control. The plate was incubated at $37^{\circ} \mathrm{C}$ for $24 \mathrm{~h}$. After the incubation $10 \mu \mathrm{l}$ of the MTT (final concentration $0.5 \mathrm{mg} / \mathrm{ml}$ ) added to each well. The plate was incubated at $37^{\circ} \mathrm{C}$ for $1 \mathrm{~h}$ and $100 \mu \mathrm{l} \mathrm{MTT}$ solvent $(10 \%$ SDS and $0.01 \mathrm{M} \mathrm{HCl})$ added for the solubilization of the formazan crystals. The cytotoxicity effect assessed by spectrophotometric measure at 570 $\mathrm{nm}$

\section{Antiviral activity assay based on a cell culture method}

In order to assess the antiviral activity of BB and BCP samples against EV-D68, a cell culture assay was implemented. Rd cells in D-MEM supplemented with $2 \%$ fetal bovine serum (FB-1001, Biosera) were seeded in 96 well plates (Biologix Europe, Germany). Cells were incubated for 24 hours at $37^{\circ} \mathrm{C}$ thus forming a monolayer. After that, the medium was removed and $200 \mu$ of each BB or BCP dilution in D-MEM medium containing 100 $\mu 1 \mathrm{EV}$-D68 virus were added on the 96 well plate in triplicates. The final concentrations of tested BB and BCP samples ranged from 16 to $0.0625 \mathrm{mg} / \mathrm{ml}$ (two-fold dilutions). The plate was incubated at $37^{\circ} \mathrm{C}$ and examined daily for development of Cytopathic Effect (CPE).

$\mathrm{BB}$ and BCP control wells containing Rd cells and BB or BCP samples served as toxicity controls, in order to differentiate CPE due to virus activity or toxicity exerted by the sample itself. Each concentration was tested in triplicates.

A cell control containing only Rd cells was used in triplicate as a negative control. For a valid test, cell control should have an intact monolayer of Rd cells. A virus control containing Rd cells and EV-D68 was used as a positive control in triplicate. When $100 \%$ CPE was observed in virus control then the assay was ended and 96 well plates were stored at $-20^{\circ} \mathrm{C}$ till further analysis.

\section{RNA Extraction and Reverse Transcription}

Every single BB/BCP sample was tested in triplicate pooled in a $1.5 \mathrm{ml}$ tube. RNA extraction was performed using $100 \mu \mathrm{l}$ of each tube according to Casas et al., 1995 based on the chaotropic agent guanidine thiocyanate. At the end of this protocol the pellet was dried and dissolved in $100 \mu$ l of sterile double-distilled, DNaseRNase free, water (DEMO S.A, Athens, Greece).

In order to detect via Real-Time PCR, the positive sense ssRNA viral genome of EV-D68, a Reverse Transcription assay was performed using random primers (Macrogen, South Korea) and FastGene Scriptase II (Nippon Genetics, Japan) according to manufacturer's protocol. The synthesized cDNA was stored at $-20^{\circ} \mathrm{C}$ till further use.

\section{Comparative Real-Time PCR assay}

Antiviral activity of samples was assessed by a comparative Real-Time PCR assay, calculating the relative concentration of viral titre in cell cultures containing different $\mathrm{BB} / \mathrm{BCP}$ concentrations compared to the viral titre used as positive control.

Three microliters of cDNAs were added in a $0.2 \mathrm{ml}$ tube containing $1 \mathrm{X}$ FastGene Mix (Nippon Genetics, Japan), 50nM ROX Low, 10pmol of each universal enterovirus primer targeting the 5'-UTR region EV2 (5'CCCCTGAATGCGGCTAATC-3'),

EV1 (5'-GATTGTCACCATAAGCAGC-3') (Monpoeho et al., 2000) and $\mathrm{dd}_{2} \mathrm{H}_{2} \mathrm{O}$ up to $20 \mu \mathrm{l}$.

The Comparative Real-Time PCR was performed at Eco48 (PCRMax) instrument at the following protocol: $95^{\circ} \mathrm{C}$ for 2 minutes, 40 cycles of $95^{\circ} \mathrm{C}$ for 5 seconds and $60^{\circ} \mathrm{C}$ for 30 seconds followed by a melting curve analysis step. Cycle threshold $(\mathrm{Ct})$ values were used to calculate the relative concentration as means of $2^{-\Delta \mathrm{Ct} \text { (Control- }}$ Sample), according to EcoStudy (PCRMax).

\section{$\mathrm{CC}_{50}, \mathrm{IC}_{50}$ and SI calculation}

Cytotoxicity concentration $50 \%\left(\mathrm{CC}_{50}\right)$ is defined as the concentration of a substance that will kill half the cells in an uninfected cell culture (Pritchett $\boldsymbol{e t}$ al., 2014). Cell toxicity of BB and BCP was calculated using the MTT assay (van Meerloo et al., 2011).

The half maximal inhibition concentration $\left(\mathrm{IC}_{50}\right)$ is a measure of the potency of a substance in inhibiting a specific biological or biochemical function (Pritchett $\boldsymbol{e}$ al., 2014). In our study $\mathrm{IC}_{50}$ was used to measure the antiviral potency of $\mathrm{BB}$ and BCP samples against EV-D68. More specifically $\mathrm{IC}_{50}$ value expresses the concentration of each $\mathrm{BB}$ sample that corresponds to $50 \%$ decrease of the viral titre and calculated via the Real-Time PCR results.
Finally, Selectivity Index (SI) is a ratio that measures the window between cytotoxicity and antiviral activity by dividing the given $\mathrm{CC}_{50}$ value into the $\mathrm{IC}_{50}$ value $\left(\mathrm{CC}_{50} / \mathrm{IC}_{50}\right)$ (Cavalli et al., 2012).

\section{Statistical Analysis}

Correlation analysis was conducted using Spearman's correlation analysis. Values of $\mathrm{p}<0.05$ were considered to indicate statistically significant differences. Statistical analysis was performed using the SPSS version 13.0 statistical package (SPSS, Inc., Chi- cago, IL, USA).

\section{RESULTS AND DISCUSSION}

Several bee products, namely honey (Shahzad \& Cohrs, 2015; Wan Yusuf et al. 2019; Watanabe et al., 2014), propolis (Gekker et al., 2005; Güler et al., 2021; Maruta \& He, 2020; Shimizu et al., 2008), bee venom (Memariani et al., 2020; Uddin et al., 2016), royal jelly (Habashy \& Abu-Serie, 2019, 2020) and even beeswax (Hassan et al., 2015) exert significant antiviral activity. Since the outbreak of Covid-19 many published reviews focus on the antiviral activities of bee products and their potential applications against the pandemic (Al-Hatamleh et al., 2020; Berretta et al., 2020; Lima et al., 2021). Surprisingly, neither BCP nor BB, have so far been investigated for their antiviral properties. Nevertheless, both $\mathrm{BCP}$ and $\mathrm{BB}$ contain a plethora of polyphenols which are renowned for their potent antiviral activity (Chen $\boldsymbol{e t}$ al., 2006; Yi $\boldsymbol{e t}$ al., 2004). In this study, $18 \mathrm{BB}$ and 2 BCP samples were assessed in vitro against Enterovirus D-68 strain.

\section{Palynological Analysis}

In a recent study of our group (Didaras et al., 2021), palynological analysis was performed and presented for the $18 \mathrm{BB}$ samples tested in this study. Moreover, in this study, palynological analysis was performed for the $2 \mathrm{BCP}$ samples to investigate whether there is any correlation between the exerted cytotoxicity, antiviral activity and botanical origin. Table 1 demonstrates the pollen grain content $(\%)$ of each BCP sample.

Table 1 Harvest period and palynologic analysis of BCP samples.

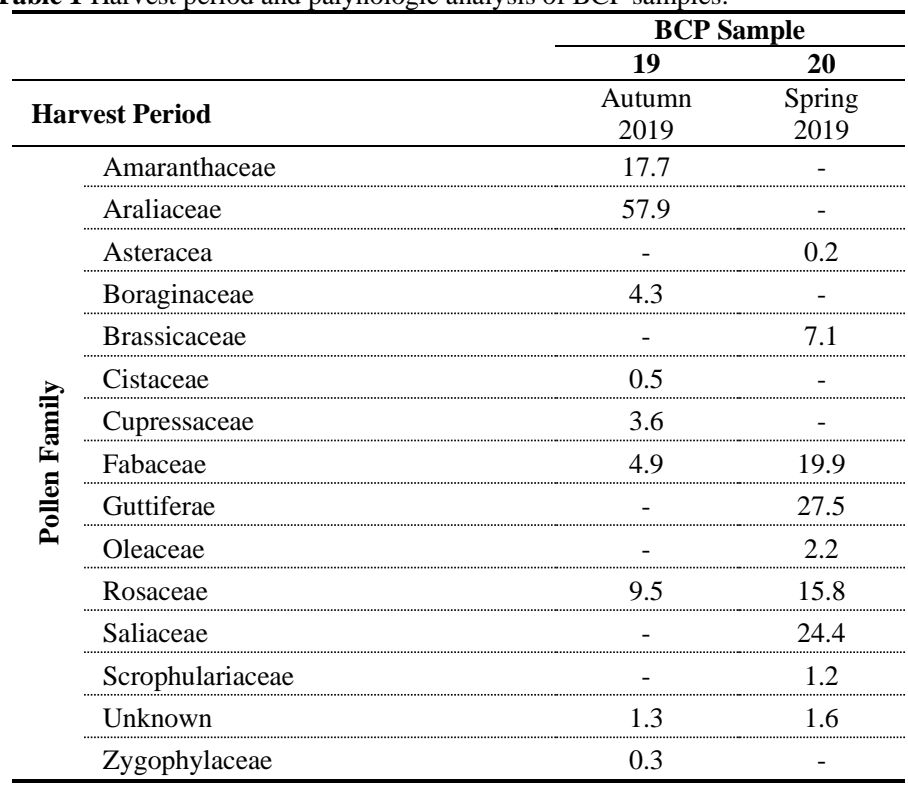

\section{MTT assay and $\mathrm{CC}_{50}$ values}

Employment of MTT assay has determined the toxicity levels of BB and BCP samples on Rd cells. As shown in Table 2, the toxicity levels expressed as $\mathrm{CC}_{50}$ values, range from 0.17 to $10.19 \mathrm{mg} / \mathrm{ml}$, indicating that high concentrations of $\mathrm{BB}$ and $\mathrm{BCP}$ are harmful to Rd cells. These levels are relatively high compared to cytotoxicity exerted by honey on MDCK cells (Watanabe et al., 2014). Nevertheless, other bee hive products show similar cytotoxicity levels in various cell lines. For example, Hatay propolis samples showed cytotoxic effects on Hep 2 cells at levels of $0.2 \mu \mathrm{g} / \mathrm{mL}$ (Yildirim et al., 2016). However, larger number of samples should be tested on Rd as well as other cell lines (f.i. MDCK, Vero and $\mathrm{MRC}-5$ ) in order to safely conclude on BB/BCP cytotoxicity.

\section{Real-Time PCR and $\mathrm{IC}_{50}$ values}

A comparative Real-time PCR assay was developed to monitor the viral copy number in the presence of tested samples. We hypothesized that, exerted antiviral activity of BB or BCP samples should lead to a decrease in EV-D68 genome copy number compared to virus control after co-inoculation of virus and samples. This 
assay targets the highly conserved 5'UTR region, a region that is widely used for the molecular detection of enteroviruses (Monpoeho et al., 2000).

Employment of the comparative Real-time PCR assay has demonstrated a decreasing copy number of EV-D68 when the virus is co-inoculated with BB or BCP samples in cell culture. These data suggest that all BB and BCP samples exert antiviral activity in a concentration-depended mode. The antiviral activity is expressed as $\mathrm{IC}_{50}$ values (Table 2) ranging from 0.048 to $5.45 \mathrm{mg} / \mathrm{ml}$.

$\mathrm{IC}_{50}$ values are highly variable (over 100-fold) suggesting that the antiviral effect could heavily depend on botanic source and geographic location in accordance to the antibacterial activity exerted by honey (Stagos $\boldsymbol{e t}$ al., 2018)

Table 2 Geographic location, botanical source and antiviral profile $\left(\mathrm{CC}_{50}, \mathrm{IC}_{50}\right.$ and SI values) of BB and BCP samples.

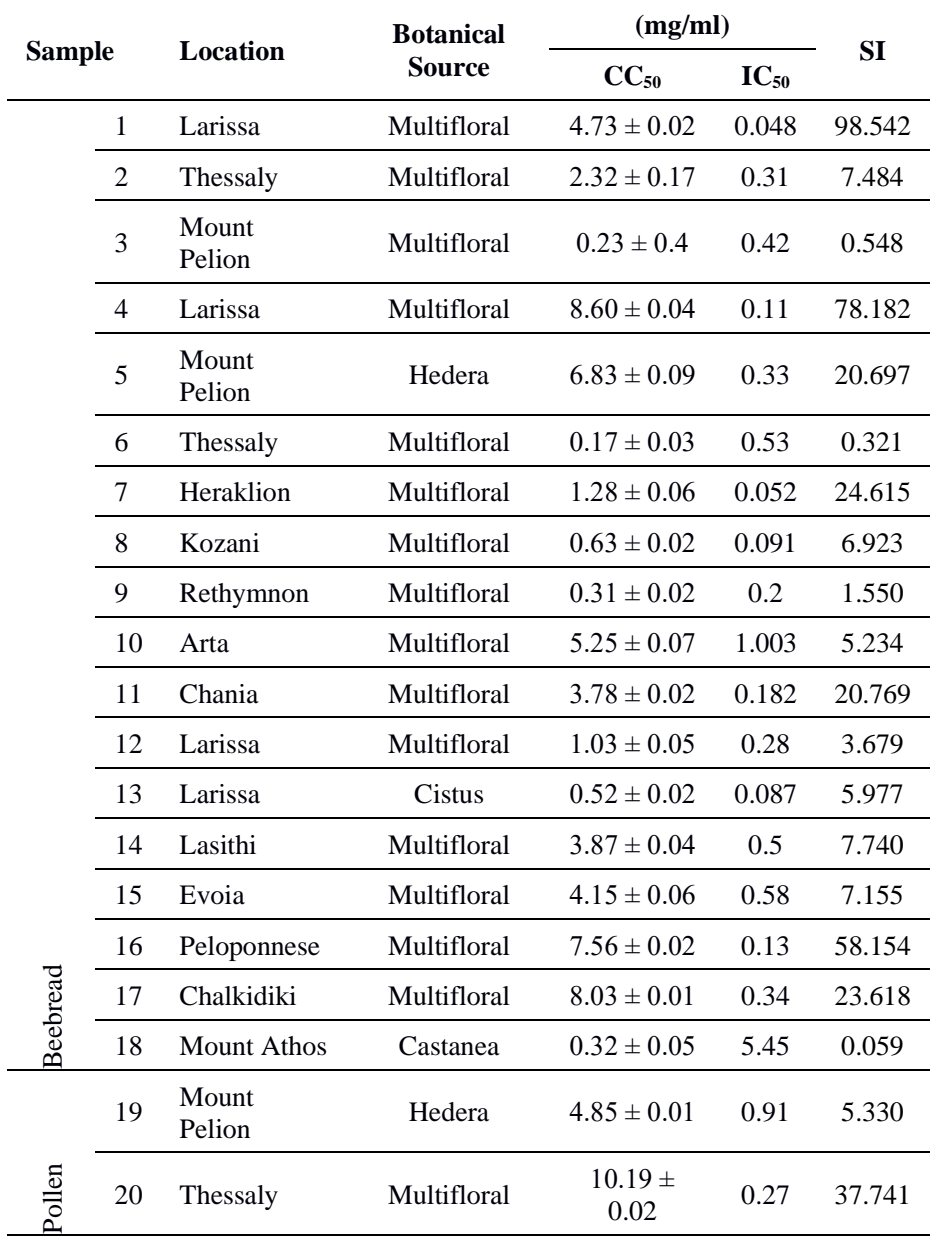

\section{Selectivity Index}

Selectivity Index (SI) values have been calculated for each sample, taking into account both $\mathrm{CC}_{50}$ and $\mathrm{IC}_{50}$ values. The higher the SI ratio, the more effective and safer a substance would be (Cavalli et al., 2012). As shown in Table 2, SI values are highly variable (1,670 -fold) ranging from 0,059 to 98,542 .

Three (3, 6 and 18$)$ out of twenty samples $(15 \%)$ demonstrated SI value lower than 1 , meaning that viral inhibition is observed in concentrations which are toxic for Rd cells. The other 17 samples (85\%) demonstrated SI value higher than 1 meaning that viral inhibition is observed in concentrations that are not toxic. Interestingly, 8 samples (40\%) demonstrated SI values higher than 20 (No $1>4>16>20>7>17>11>5$ ), meaning that the $\mathrm{IC}_{50}$ concentration is more than 20 times smaller than the correspondent $\mathrm{CC}_{50}$ concentration, an indication of potent antiviral effect.

\section{Correlation Analysis}

$\mathrm{BCP}$ is fermented to $\mathrm{BB}$, a process that includes bees, plants and the microbiome. Each partner might be a source of antiviral compounds such as phytochemicals (Didaras et al., 2020; Ha et al., 2020), bee secretions (Habashy \& Abu-Serie, 2020) and secondary metabolites (Esawy et al., 2011; Zhang et al., 2015) that presumably contribute to the antiviral activity.

In order to elucidate the role of plants, the botanical origin of the samples was taken into account. Statistical analysis was performed in order to assess the correlation among the $\mathrm{CC}_{50}, \mathrm{IC}_{50}$ and SI values and the major pollen families present in each BB and BCP sample. Only the dominant (> 10\%) pollen families were included. Moreover, pollen families that were present in less than three samples were excluded from further analysis.
A negative strong correlation between $\mathrm{IC}_{50}$ values and Brassicaceae pollen conten was observed $(r=0.90 ; \mathrm{p}<0.05)$. This correlation indicates that compounds present in Brassicaceae pollen might be responsible for the antiviral activity of these samples though further investigation of this hypothesis is needed. Interestingly, a strongly positive and statistically significant correlation between $\mathrm{CC}_{50}$ values and pollen content was not observed but a strong positive correlation $(r=0.90 ; p<0.05)$ was observed between Rosaceae pollen content and SI values (Table 3).

Brassicaceae family, also known as the mustard family, includes plants used in traditional medicine such as Sinapis nigra, and Sinapis alba as well as cultivated plants with high antioxidant potency like cabbage, broccoli, and cauliflower (Didaras et al., 2021). On the other hand, Rosaceae family includes many fruit plants. Future research will reveal whether the pollen of certain Brassicaceae and Rosaceae species detected in BB might contain potent antiviral compounds.

Table 3 Correlation coefficient (r) values estimated from correlation analysis of $\mathrm{CC}_{50}, \mathrm{IC}_{50}$ and $\mathrm{SI}$ values against dominant families of pollen content in each sample.

\begin{tabular}{lccc}
\hline Pollen Family & IC $_{\mathbf{5 0}}$ & $\mathbf{C C}_{\mathbf{5 0}}$ & $\mathbf{S I}$ \\
\hline Araliaceae & $1,000^{* *}$ & 0.500 & $\begin{array}{c}\overline{-} \\
0.500\end{array}$ \\
\hline Boraginaceae & 0.500 & $-1,000^{* *}$ & $\begin{array}{c}- \\
0.500\end{array}$ \\
\hline Brasicaceae &,$- 900^{*}$ & 0.600 & 0.600 \\
\hline Cistaceae & -0.400 & 0.200 & 0.400 \\
\hline Ericaceae & $1,000^{* *}$ & 0.500 & $\begin{array}{c}- \\
\text { Fabaceae }\end{array}$ \\
\hline Fagaceae & 0.095 & 0.238 & 0.048 \\
\hline Guttiferae & 0.200 & -0.800 & $\begin{array}{c}- \\
0.200\end{array}$ \\
\hline Rosaceae & 0.600 & 0.429 & 0.200 \\
\hline Saliacea & -0.300 & 0.300 &, $900^{*}$ \\
\hline
\end{tabular}

Legend: *Correlation is statistically significant at $\mathrm{p}<0.05$, **Correlation is statistically significant at $\mathrm{p}<0.01$

EV-D68, is an emerging enterovirus, causing outbreaks, associated with mild and severe respiratory illness mainly affecting children (Aliabadi et al., 2016; Hu et al., 2019; Mishra et al., 2019). No specific therapy is available neither to treat EVD68 infection nor to prevent virus associated diseases (Oermann et al., 2015) Therefore, natural products with potent antiviral activity could be considered as a source of novel therapeutic agents, helping to overcome this serious public health issue. Furthermore, no hive product has been assessed so far regarding its antiviral activity against EV-D68.

Although a direct comparison is not feasible, $7 \mathrm{BB}$ and one $\mathrm{BCP}$ samples have demonstrated potent antiviral activity compared to other bee hive products. A recent study has shown that the well-known manuka honey exerted higher activity against the influenza virus compared to other honeys (Watanabe et al., 2014) but still its SI value is lower than five of our samples against EV-D68.

\section{CONCLUSION}

This is the first study to test the antiviral properties of BCP and BB. We have shown that all BB and BCP samples exert significant antiviral activity against the tested virus (EV-D68) and in most cases viral inhibition is observed at concentrations that were non toxic for Rd cells. Although the correlation of antiviral potency to botanical origin is not totally conclusive, it has revealed that certain Brassicaceae and Rosaceae species correlate with higher antiviral activity. Further investigation will elucidate the antiviral compounds present in Greek BCP and $\mathrm{BB}$ and might lead to development of novel therapeutic agents.

Acknowledgments: We are very grateful to beekeepers who provided the BB and BCP samples used in this study.

\section{REFERENCES}

Abu-Serie, M. M., \& Habashy, N. H. (2019). Two purified proteins from royal jelly with in vitro dual anti-hepatic damage potency: Major royal jelly protein 2 and its nove isoform X1. International Journal of Biological Macromolecules, 128, 782-795. https://doi.org/10.1016/j.ijbiomac.2019.01.210

Al-Hatamleh, M. A. I. I., Hatmal, M. M., Sattar, K., Ahmad, S., Mustafa, M. Z., Bittencourt, M. D. C., \& Mohamud, R. (2020). Antiviral and Immunomodulatory Effects of Phytochemicals from Honey against COVID-19: Potential Mechanisms of Action and $\begin{array}{llll}\text { Future } & \text { Directions. } & \text { Molecules, } & \text { 25(21), }\end{array}$ https://doi.org/10.3390/molecules25215017

Aliabadi, N., Messacar, K., Pastula, D. M., Robinson, C. C., Leshem, E., Sejvar, J. J. Nix, W. A., Oberste, M. S., Feikin, D. R., \& Dominguez, S. R. (2016). Enterovirus D68 infection in children with acute flaccid Myelitis, Colorado, USA, 2014. Emerging Infectious Diseases, 22(8), 1387-1394. https://doi.org/10.3201/eid2208.151949

Berretta, A. A., Silveira, M. A. D., Cóndor Capcha, J. M., \& De Jong, D. (2020). Propolis 
and its potential against SARS-CoV-2 infection mechanisms and COVID-19 disease $\begin{array}{llll}\text { Biomedicine \& Pharmacotherapy, } & 131, & 10622 .\end{array}$ https://doi.org/10.1016/j.biopha.2020.110622

Casas, I., Powell, L., Klapper, P. E., \& Cleator, G. M. (1995). New method for the extraction of viral RNA and DNA from cerebrospinal fluid for use in the polymerase chain reaction assay. Journal of Virological Methods, 53(1), 25-36. https://doi.org/10.1016/0166-0934(94)00173-E

Cavalli, R., Donalisio, M., Bisazza, A., Civra, A., Ranucci, E., Ferruti, P., \& Lembo, D. (2012). Enhanced Antiviral Activity of Acyclovir Loaded into Nanoparticles. In N Düzgüneş (Ed.), Methods in Enzymology (Vol. 509, pp. 1-19). Academic Press Inc. https://doi.org/10.1016/B978-0-12-391858-1.00001-0

Chen, L., Li, J., Luo, C., Liu, H., Xu, W., Chen, G., Liew, O. W., Zhu, W., Puah, C. M., Shen, X., \& Jiang, H. (2006). Binding interaction of quercetin-3- $\beta$-galactoside and its synthetic derivatives with SARS-CoV 3CLpro: Structure-activity relationship studies reveal salient pharmacophore features. Bioorganic and Medicinal Chemistry, 14(24), 8295-8306. https://doi.org/10.1016/j.bmc.2006.09.014

Didaras, N. A., Kafantaris, I., Dimitriou, T. G., Mitsagga, C., Karatasou, K., Giavasis, I., Stagos, D., Amoutzias, G. D., Hatjina, F., \& Mossialos, D. (2021). Biological Properties of Bee Bread Collected from Apiaries Located across Greece. Antibiotics, 10(5), 555. https://doi.org/10.3390/antibiotics10050555

Didaras, N. A., Karatasou, K., Dimitriou, T. G., Amoutzias, G. D., \& Mossialos, D (2020). Antimicrobial Activity of Bee-Collected Pollen and Beebread: State of the Art and Future Perspectives. Antibiotics, 9(11) 811. https://doi.org/10.3390/antibiotics9110811

Esawy, M. A., Ahmed, E. F., Helmy, W. A., Mansour, N. M., El-Senousy, W. M., \& ElSafty, M. M. (2011). Production of levansucrase from novel honey Bacillus subtilis isolates capable of producing antiviral levans. Carbohydrate Polymers, 86(2), 823-830. https://doi.org/10.1016/i.carbpol.2011.05.035

Gekker, G., Hu, S., Spivak, M., Lokensgard, J. R., \& Peterson, P. K. (2005). Anti-HIV1 activity of propolis in CD4+ lymphocyte and microglial cell cultures. Journal of Ethnopharmacology, 102(2), 158-163. https://doi.org/10.1016/i.jep.2005.05.045

Güler, H. I., Tatar, G., Yildiz, O., Osman Belduz, A., Kolayli, S., Guler, H. I., Tatar, G. Yildiz, O., Belduz, A. O., \& Kolayli, S. (2021). Investigation of potential inhibitor properties of ethanolic propolis extracts against ACE-II receptors for COVID-19 treatment by molecular docking study. Archives of Microbiology, 1, 3. https://doi.org/10.1007/s00203-021-02351-1

Ha, T. K. Q., Lee, B. W., Nguyen, N. H., Cho, H. M., Venkatesan, T., Doan, T. P., Kim E., \& Oh, W. K. (2020). Antiviral Activities of Compounds Isolated from Pinus densiflora (Pine Tree) against the Influenza A Virus. Biomolecules, 10(5), 711 https://doi.org/10.3390/biom10050711

Habashy, N. H., \& Abu-Serie, M. M. (2019). Major royal-jelly protein 2 and its isoform $\mathrm{X} 1$ are two novel safe inhibitors for hepatitis C and B viral entry and replication. International Journal of Biological Macromolecules, 141, 1072-1087. https://doi.org/10.1016/j.ijbiomac.2019.09.080

Habashy, N. H., \& Abu-Serie, M. M. (2020). The potential antiviral effect of major roya jelly protein 2 and its isoform $\mathrm{X} 1$ against severe acute respiratory syndrome coronavirus 2 (SARS-CoV-2): Insight on their sialidase activity and molecular docking. Journal of Functional Foods, 75, 104282. https://doi.org/10.1016/j.jff.2020.104282

Hassan, M. I., Mohamed, A. F., Amer, M. A., Hammad, K. M., \& Riad, S. A. (2015) Monitoring of the antiviral potential of bee venom and wax extracts against Adeno-7 (DNA) and Rift Valley fever virus (RNA) viruses models. Journal of the Egyptian Society of Parasitology, 45(1), 193-198. https://doi.org/10.12816/0010865

Hierholzer, J. C., \& Killington, R. A. (1996). Virus isolation and quantitation. In B. W. Mahy \& H. O. Kangro (Eds.), Virology Methods Manual (pp. 25-46). Academic Press. https://doi.org/10.1016/B978-012465330-6/50003-8

Hood, J. L., Jallouk, A. P., Campbell, N., Ratner, L., \& Wickline, S. A. (2013). Cytolytic nanoparticles attenuate HIV-1 infectivity. Antiviral Therapy, 18(1), 95-103. https://doi.org/10.3851/IMP2346

Hossain, K. S., Hossain, M. G., Moni, A., Rahman, M. M., Rahman, U. H., Alam, M. Kundu, S., Rahman, M. M., Hannan, M. A., \& Uddin, M. J. (2020). Prospects of honey in fighting against COVID-19: pharmacological insights and therapeutic promises. Heliyon, 6(12), e05798. https://doi.org/10.1016/J.HELIYON.2020.E05798

Hu, Y. L., Huang, L. M., Lu, C. Y., Fang, T. Y., Cheng, A. L., \& Chang, L. Y. (2019) Manifestations of enterovirus D68 and high seroconversion among children attending a kindergarten. Journal of Microbiology, Immunology and Infection, 52(6), 858-864. https://doi.org/10.1016/j.jmii.2019.04.010

Lee, I. K., Hwang, B. S., Kim, D. W., Kim, J. Y., Woo, E. E., Lee, Y. J., Choi, H. J., \& Yun, B. S. (2016). Characterization of Neuraminidase Inhibitors in Korean Papave rhoeas Bee Pollen Contributing to Anti-Influenza Activities in Vitro. Planta Medica 82(6), 524-529. https://doi.org/10.1055/s-0041-111631

Lima, W. G., Brito, J. C. M. M., Cruz Nizer, W. S., da Cruz Nizer, W. S., Nizer, W. S da C., \& Cruz Nizer, W. S. (2021). Bee products as a source of promising therapeutic and chemoprophylaxis strategies against COVID-19 (SARS-CoV-2). Phytotherapy Research, 35(2), 743-750. https://doi.org/10.1002/ptr.6872

Maruta, H., \& He, H. (2020). PAK1-blockers: Potential Therapeutics against COVID 19. Medicine in Drug Discovery, 6, 100039 https://doi.org/10.1016/j.medidd.2020.100039

Memariani, H., Memariani, M., Moravvej, H., \& Shahidi-Dadras, M. (2020). Melittin a venom-derived peptide with promising anti-viral properties. European Journal of Clinical Microbiology \& Infectious Diseases, 39(1), 5-17. https://doi.org/10.1007/s10096-019-03674-0

Midgley, C. M., Watson, J. T., Nix, W. A., Curns, A. T., Rogers, S. L., Brown, B. A. Conover, C., Dominguez, S. R., Feikin, D. R., Gray, S., Hassan, F., Hoferka, S., Jackson, M. A., Johnson, D., Leshem, E., Miller, L., Nichols, J. B., Nyquist, A. C., Obringer, E., Gerber, S. I. (2015). Severe respiratory illness associated with a nationwide outbreak of enterovirus D68 in the USA (2014): A descriptive epidemiological investigation. The
Lancet Respiratory Medicine, 3(11), 879-887. https://doi.org/10.1016/S2213 2600(15)00335-5

Mishra, N., Ng, T. F. F., Marine, R. L., Jain, K., Ng, J., Thakkar, R., Caciula, A., Price, A., Garcia, J. A., Burns, J. C., Thakur, K. T., Hetzler, K. L., Routh, J. A., KonopkaAnstadt, J. L., Nix, W. A., Tokarz, R., Briese, T., Oberste, M. S., \& Lipkin, W. I. (2019) Antibodies to Enteroviruses in Cerebrospinal Fluid of Patients with Acute Flaccid Myelitis. MBio, 10(4), e01903-19. https://doi.org/10.1128/mBio.01903-19

Monpoeho, S., Dehée, A., Mignotte, B., Schwartzbrod, L., Marechal, V., Nicolas, J. C. Billaudel, S., \& Férré, V. (2000). Quantification of enterovirus RNA in sludge samples using single tube real-time RT-PCR. BioTechniques, 29(1), 88-93. https://doi.org/10.2144/00291st03

Oberste, M. S., Maher, K., Schnurr, D., Flemister, M. R., Lovchik, J. C., Peters, H., Sessions, W., Kirk, C., Chatterjee, N., Fuller, S., Hanauer, J. M., \& Pallansch, M. A (2004). Enterovirus 68 is associated with respiratory illness and shares biological features with both the enteroviruses and the rhinoviruses. Journal of General Virology, 85(9), 2577-2584. https://doi.org/10.1099/vir.0.79925-0

Oermann, C. M., Schuster, J. E., Conners, G. P., Newland, J. G., Selvarangan, R., \& Jackson, M. A. (2015). Enterovirus D68: A focused review and clinical highlights from the 2014 U.S. outbreak. Annals of the American Thoracic Society, 12(5), 775-781. https://doi.org/10.1513/AnnalsATS.201412-592FR

Pełka, K., Otłowska, O., Worobo, R. W., \& Szweda, P. (2021). Bee Bread Exhibits Higher Antimicrobial Potential Compared to Bee Pollen. Antibiotics, 10(2), 125 https://doi.org/10.3390/antibiotics10020125

Pritchett, J. C., Naesens, L., \& Montoya, J. (2014). Treating HHV-6 Infections: The Laboratory Efficacy and Clinical Use of Anti-HHV-6 Agents. In L. Flamand, I Lautenschlager, G. R. F. Krueger, \& D. V. Ablashi (Eds.), Human Herpesviruses HHV $6 A, \quad H H V-6 B$, and $H H V-7$ (Third edit, pp. 311-331). Elsevier B.V. https://doi.org/10.1016/B978-0-444-62703-2.00019-7

Shahzad, A., \& Cohrs, R. J. (2015). In vitro antiviral activity of honey against varicella zoster virus (VZV): A translational medicine study for potential remedy for shingles. Transl Biomed, 3(2), 2. https://doi.org/10.3823/434

Shimizu, T., Hino, A., Tsutsumi, A., Yong, K. P., Watanabe, W., \& Kurokawa, M. (2008). Anti-influenza virus activity of propolis in vitro and its efficacy against influenza infection in mice. Antiviral Chemistry and Chemotherapy, 19(1), 7-13 https://doi.org/10.1177/095632020801900102

Stagos, D., Soulitsiotis, N., Tsadila, C., Papaeconomou, S., Arvanitis, C., Ntontos, A. Karkanta, F., Adamou-Androulaki, S., Petrotos, K., Spandidos, D. A., Kouretas, D., \& Mossialos, D. (2018). Antibacterial and antioxidant activity of different types of honey derived from Mount Olympus in Greece. International Journal of Molecular Medicine, 42(2), 726-734. https://doi.org/10.3892/ijmm.2018.3656

Uddin, M. B., Lee, B.-H. H., Nikapitiya, C., Kim, J.-H. H., Kim, T.-H. H., Lee, H.-C C., Kim, C. G. C.-J. J., Lee, J.-S. S., \& Kim, C. G. C.-J. J. (2016). Inhibitory effects of bee venom and its components against viruses in vitro and in vivo. Journal of Microbiology, 54(12), 853-866. https://doi.org/10.1007/s12275-016-6376-1

van Meerloo, J., Kaspers, G. J. L., \& Cloos, J. (2011). Cell Sensitivity Assays: The MTT Assay. In I. Cree (Ed.), Cancer Cell Culture. Methods in Molecular Biology (Methods and Protocols) (pp. 237-245). Humana Press. https://doi.org/10.1007/978-1-61779 080-5_20

Vogt, M. R., Fu, J., Kose, N., Williamson, L. E., Bombardi, R., Setliff, I., Georgiev, I S., Klose, T., Rossmann, M. G., Bochkov, Y. A., Gern, J. E., Kuhn, R. J., \& Crowe, J. E. (2020). Human antibodies neutralize enterovirus D68 and protect against infection and paralytic disease. Science Immunology, 5(49), 4902 https://doi.org/10.1126/sciimmunol.aba4902

Wan Yusuf, W. N., Wan Mohammad, W. M. Z., Gan, S. H., Mustafa, M., Abd Aziz, C. B., \& Sulaiman, S. A. (2019). Tualang honey ameliorates viral load, CD4 counts and improves quality of life in asymptomatic human immunodeficiency virus infected patients. Journal of Traditional and Complementary Medicine, 9(4), 249-256. https://doi.org/10.1016/j.jtcme.2018.05.003

Watanabe, K., Rahmasari, R., Matsunaga, A., Haruyama, T., \& Kobayashi, N. (2014) Anti-influenza Viral Effects of Honey In Vitro: Potent High Activity of Manuka Honey. Archives of Medical Research, 45(5), 359-365. https://doi.org/10.1016/j.arcmed.2014.05.006

Yi, L., Li, Z., Yuan, K., Qu, X., Chen, J., Wang, G., Zhang, H., Luo, H., Zhu, L., Jiang, P., Chen, L., Shen, Y., Luo, M., Zuo, G., Hu, J., Duan, D., Nie, Y., Shi, X., Wang, W.,

Xu, X. (2004). Small Molecules Blocking the Entry of Severe Acute Respiratory Syndrome Coronavirus into Host Cells. Journal of Virology, 78(20), 11334-11339. https://doi.org/10.1128/jvi.78.20.11334-11339.2004

Yildirim, A., Duran, G. G., Duran, N., Jenedi, K., Bolgu, B. S., Miraloglu, M., \& Muz M. (2016). Antiviral activity of hatay propolis against replication of herpes simplex virus type 1 and type 2. Medical Science Monitor, 22, 422-430. https://doi.org/10.12659/MSM.897282

Zhang, T., Ren, L., Luo, M., Li, A., Gong, C., Chen, M., Yu, X., Wu, J., Deng, Y., \& Huang, F. (2015). Enterovirus D68-Associated Severe Pneumonia, China, 2014 Emerging Infectious Diseases, 21(5), 916-918. https://doi.org/10.3201/eid2105.150036 